\title{
PENGARUH PENERAPAN AUDIT E-COMMERCE TERHADAP KINERJA AUDITOR: STUDI EMPIRIS PADA KANTOR AKUNTAN PUBLIK DI SURABAYA, INDONESIA
}

\author{
Muhammad Ismail Saleh ${ }^{1 *}$, Muhammad Wisnu Girindratama \\ ${ }^{1}$ Fakultas Ekonomi dan Bisnis, Universitas Airlangga, Surabaya, Indonesia \\ ${ }^{2}$ Fakultas Bisnis dan Ekonomika, Universitas Surabaya, Surabaya, Indonesia
}

DOI: https://doi.org/10.24123/jati.v14i2.4669

\begin{abstract}
This study aims to identify using empirical research how the impact of E-commerce on the auditing profession. The object of this research is the auditor who works at the Public Accounting Firm (KAP) in the city of Surabaya. Data collection was done by doing a survey through a questionnaire media. The primary data generated by 60 questionnaires can be processed using Partial Least Square. Evaluation of the model in PLS is done by evaluating the outer model and inner model. The data in this study were collected through questionnaires and analyzed by using a simple linear regression model. The results of the study found that the implementation of e-audit has a positive and significant effect on auditor performance. The auditor performance is influenced by an e-audit factor of $83 \%$ and the remaining is influenced by other factors.
\end{abstract}

Keywords: Auditor Performance; E-audit Implementation; Public Accounting Firm.

\begin{abstract}
Abstrak
Penelitian ini bertujuan untuk mengidentifikasi dengan penelitian empiris sejauh mana dampak dari Ecommerce pada profesi audit. Obyek dari penelitian ini adalah auditor yang bekerja di Kantor Akuntan Publik (KAP) Di Kota Surabaya. Pengambilan data dilakukan dengan metode survey melalui media kuesioner. Data primer yang dihasilkan sebanyak 60 kuesioner dapat diolah menggunakan Partial Least Square. Evaluasi model dalam PLS dilakukan dengan melakukan evaluasi pada outer model dan inner model. Data dalam penelitian ini dikumpulkan dengan kuesioner dan dianalisis dengan regresi linier sederhana. Hasil studi menemukan bahwa pelaksanaan e-audit memiliki pengaruh positif dan signifikan terhadap kinerja auditor. kinerja auditor dipengaruhi oleh faktor e-audit (83\%) dan yang tersisa dipengaruhi oleh faktor lain.
\end{abstract}

Kata kunci: E-audit implementasi; Kantor Akuntan Publik; Kinerja Auditor. 


\section{PENDAHULUAN}

\section{Latar Belakang}

Indonesia sebagai negara berkembang tidak biasa menghadapi tantangan yang berat dalam memasuki era globalisasi dan perdagangan bebas, satu-satunya hal yang harus dilaksanakan adalah selalu berusaha menjadi yang terdepan atau paling tidak, tidak ketinggalan. Salah satu sektor yang sangat penting dan sangat terasa dampak serta perubahannya dalam memasuki era globalisasi ini adalah sektor bisnis. Dalam era baru dalam dunia bisnis yang semakin global tersebut, bisnis memanfaatkan media elektronik internet, sudah pasti merupakan sektor yang utama dan melalui sektor ini diharapkan dapat memberikan kesempatan atau peluang yang sama bagi para pelaku bisnis baik kecil, menengah, maupun besar untuk dapat bersaing.

Dalam era globalisasi dan perdagangan bebas tersebut, persaingan sudah sangat ketat dan tidak mengenal batas sehingga dapat dikatakan bahwa perusahaan-perusahaan kelas dunia tersebut dapat bersaing dengan perusahaan lainnya di dunia, dalam hal tersebut perusahaanperusahaan tersebut juga harus mempunyai pangsa pasar yang luas, hubungan yang baik dengan konsumen yang dalam era globalisasi ini dapat berada dimanapun.

Dalam mencapai daya saing serta keunggulan-keunggulan tersebut, suatu perusahaan merambah atau memperluas kegiatan usahanya dengan menggunakan internet sebagai medianya menjadi bisnis online. Langkah-langkah awal yang diambil perusahaan tersebut yaitu membuat situs web yang menampilkan profil perusahaan serta produk apa saja yang dihasilkan perusahaan tersebut, kemudian perusahaan tersebut dapat melaksanakan pemasaran produkproduknya melalui situs web tersebut dan kemudian konsumen juga dapat melakukan pembelian produk melalui situs web perusahaan tersebut.

Kegiatan konsumen dalam membeli produk suatu perusahaan, dengan cara melakukan pemesanan maupun pembelian melalui situs web perusahaan produsen produk tersebut, maka konsumen tersebut dikatakan telah melakukan pembelian secara online.

Kegiatan bisnis atau lebih sederhananya melakukan pertukaran, termasuk jual beli, produk dan jasa yang membutuhkan transportasi pemindahan, baik secara fisik maupun digital dari satu lokasi ke lokasi lain melalui media transmisi elektronik inilah yang disebut sebagai "E-Commerce" Menurut Jeffrey, Electronic Commerce atau E-Commerce adalah kegiatan komersial yang mengambil tempat bagian dari komputer dihubungkan melalui suatu jaringan. E-Commerce dapat terjadi antara pengguna dan pemasok melalui jasa pelayanan online. 
Internet atau BBS, atau antara pemasok dan pelanggan komputer melalui electronic data interchange (EDI) yang juga disebut e-commerce.

Elektronik commerce adalah tentang melakukan bisnis secara elektronik. Didasari dengan pemrosesan secara elektronik dan transmisi data, termasuk teks, suara dan video. Hal tersebut mencakup berbagai jenis aktivitas termasuk jual-beli barang dan jasa secara elektronik, pengiriman data digital secara online, transfer dana secara elektronik, jual beli saham secara elektronik, bills of lading, lelang komersial, kerja sama rancang dan bangun, pengadaan secara online, procurement public, direct consumer marketing dan layanan puma jual. E•commerce juga melibatkan produk (contoh: produk konsumsi, alat-alat medis) dan jasa (contoh: layanan informasi, jasa finansial dan hukum), aktivitas-aktivitas tradisional (contoh: kesehatan, pendidikan), dan aktivitas-aktivitas barn (contoh: mal virtual). Menurut Thomas O 'Daniel "Electronic commerce, Management Economics Marketing and Technology".

Seiring dengan waktu dan persaingan teknologi yang semakin ketat yang menyebabkan salah satu perusahaan-perusahaan online atau yang melakukan bisnis ecommerce pun semakin banyak bermunculan, bisnis e-commerce ini sudah bukan merupakan suatu trend bisnis musiman tetapi muncul karena kebutuhan pasar atau konsumen, persaingan yang semakin ketat dan kemajuan teknologi.

Di sisi lain, seiring pertumbuhan jumlah perusahaan-perusahaan online di Indonesia ini, timbul pula kebutuhan perusahaan-perusahaan tersebut atas jasa audit dari kantor-kantor akuntan publik. Jasa audit yang dibutuhkan pun tidak sama dengan jasa audit yang biasa diberikan oleh kantor-kantor akuntan publik. Kepada perusahaan-perusahaan yang tidak melakukan kegiatan bisnis e•commerce atau yang dapat disebut sebagai perusahaanperusahaan yang offline seperti perusahaan-perusahaan di Indonesia pada umumnya. Jasa audit yang diberikan tersebut adalah jasa audit e-commerce Di luar negeri telah menjadi hal yang umum suatu kantor akuntan publik memberikan jasa audit e-commerce. Menurut pengamatan penulis, Di Indonesia jasa audit e-commerce ini belum terlalu dikenal maupun dimanfaatkan belum berkembang seiring dengan keadaan-keadaan yang telah penulis tuturkan diatas.

Praktisi di lapangan audit dan organisasi profesional seperti Dewan Standar Auditing (ASB) telah membayar lebih memperhatikan ketergantungan organisasi pada sistem EDP, misalnya dengan menerbitkan Pernyataan Standar Auditing (SAS). Sementara di Indonesia, Institute Akuntan Publik Indonesia (IAPI) telah mengadopsi SAS dalam Standar Profesional 
Akuntan Publik (SPAP), yang berfungsi sebagai panduan bagi auditor dalam melakukan audit entitas yang menggunakan sistem EDP.

Penggunaan sistem EDP dalam bisnis memiliki dampak seperti dua sisi mata uang dimana satu sisi memberikan banyak kemudahan, tetapi di sisi lain dapat melemahkan dokumen keandalan sebagai bukti audit karena ada pergeseran bukti audit dari bukti dokumen ke bukti elektronik (Evi Maria, Yayuk Hariyani 2104). Auditor diwajibkan mengikuti perkembangan teknologi informasi (TI) saat melakukan audit kerja. Evolusi e-commerce, dengan menggunakan jaringan publik seperti Internet sebagai infrastruktur teknologi untuk mendukung pelaksanaan informasi dan komunikasi saluran, telah menghasilkan dampak besar pada apa yang menyangkut pelaksanaan sistem pengendalian internal dan sistem informasi praktik audit, komersial ketika transaksi dilakukan secara elektronik. (Carlos Santos,2013)

Kantor Akuntan Publik (KAP) harus menjaga dan memelihara kualitas lingkungan bisnis di tengah audit dan cepat berkembang sistem EDP karena jika auditor gagal untuk menjaga kwalitas dan kinerja dengan baik, akan ada tuntutan hukum oleh pihak ketiga. Sejak munculnya skandal Enron pada tahun 2001, profesi akuntan publik telah mengalami perubahan besar sesuai dengan publikasi Sarbanes-Oxley yang menempatkan berdampak pada akurasi dan transparansi pelaporan keuangan perusahaan (Sesepuh et al. 2010). Auditor dituntut tidak hanya mampu menguji keuangan alur transaksi, tapi juga memeriksa praktek kerja manajemen. proses audit menggunakan Computer Assisted Audit Techniques (CAATs) atau e-audit tidak bisa lagi ditunda untuk diterapkan oleh perusahaan karena mayoritas klien baik perusahaan besar dan kecil, telah menggunakan sistem teknologi untuk melakukan proses transaksi. Selain itu, penggunaan e-audit dapat mengatasi risiko penipuan dan dapat mendeteksi kegiatan dengan potensi penipuan (Olasanmi,2013) sehingga dapat membantu auditor dalam melaksanakan tugas pemeriksaan secara efektif dan efisien (Hartoyo, 2011).

Konsep e-audit di sektor publik telah dimasukkan dalam rencana strategis Badan Indonesian Pemeriksa Keuangan (BPK RI) 2011-2015 dalam rangka manajemen inspeksi dan tanggung jawab keuangan negara. Konsep ini direncanakan untuk mengatasi masalah yang terkait dengan waktu pemeriksaan singkat dan terbatasnya jumlah auditor karena meningkatnya jumlah negara entitas manajer keuangan.

Penerapan konsep e-audit di sektor publik diharapkan dapat memberikan manfaat dalam mencegah, mendeteksi dan melacak penipuan dalam pengelolaan dan pertanggungjawaban keuangan negara (BPK RI, 2012). BPK dapat menggunakan pemeriksa 
eksternal seperti akuntan publik yang bekerja di perusahaan yang terdaftar di BPK untuk membantu tugas pemeriksaan keuangan negara (UU No. 15 Tahun 2004 pasal 9). Selain untuk KAP, Hartoyo (2011) menyatakan bahwa penggunaan e-audit bukanlah titik baru dalam membantu proses pemeriksaan auditee. Namun, proses pemeriksaan menggunakan TI sering mengalami masalah dan juga gagal sering karena proses audit berlari tidak aman dan ilegal (Hartoyo, 2011). Oleh karena itu, peraturan, hardware, software dan sumber daya manusia haru siap untuk sukses e-audit implementasi.

\section{Rumusan Masalah}

1. Bagaimana Pengaruh Penerapan E-audit di KAP terhadap Kinerja Auditor?

\section{Tujuan Penelitian}

1. Untuk memberikan bukti empiris tentang pengaruh Penerapan E-audit di KAP terhadap Kinerja Auditor.

\section{TELAAH TEORETIS}

\section{E-Audit}

Sesepuh et al., (2010) mendefinisikan auditing sebagai suatu proses pengumpulan dan penilaian bukti informasi yang relevan untuk menentukan dan melaporkan tingkat kesesuaian informasi dengan kriteria yang telah ditetapkan. Auditing harus dilakukan oleh orang yang kompeten dan independen. E-audit tidak terlalu berbeda dari audit, hanya proses pengumpulan bukti-bukti, dan evaluasi bukti performed dengan komputer. Bukti yang dikumpulkan untuk dievaluasi juga tidak lagi dalam bentuk hardcopy tapi file data komputer. Computer Assisted Audit Techniques (CAATs) dibagi menjadi tiga (3) pendekatan yaitu sekitar audit komputer, audit melalui komputer, dan computer dibantu audit.

\section{Kinerja Auditor}

Kinerja Auditor menurut Mulyadi (2010) adalah akuntan publik organisasi yang berstandar yang melaksanakan pemeriksaan tugas tujuan laporan keuangan perusahaan atau organisasi lain dengan tujuan untuk menentukan apakah laporan keuangan disajikan secara wajar sesuai dengan prinsip akuntansi yang berlaku umum atau tidak, dalam semua hal yang material, posisi dan operasi hasil keuangan perusahaan. Kinerja Auditor sebagai evaluasi 
terhadap pekerjaan yang dilakukan oleh Manajemen dan karyawan langsung (Trisnaningsih, 2007). Larkin (1990) menyatakan bahwa kinerja auditor terdiri dari kemampuan, professional kepuasan. komitmen, motivasi, dan pekerjaan Kinerja adalah suatu kondisi yang harus diketahui dan dikonfirmasikan kepada pihak tertentu untuk mengetahui tingkat pencapaian hasil terkait dengan visi organisasi. Esya (2008) mendefinisikan kinerja auditor sebagai pekerjaan potensial ekspresi auditor dalam bentuk perilaku kerja auditor dalam melaksanakan tugas audit untuk mencapai hasil yang optimal yang diukur dengan menggunakan dua (2) faktor dimensi, faktor objektif dan faktor subjektif. Indikator dari faktor objektif adalah hasil dan disiplin kerja. Sementara indikator faktor subjektif adalah inisiatif, kerjasama dan loyalitas.

\section{Konsep Kantor Akuntan Publik:}

Kantor Akuntan Publik (KAP) adalah badan usaha yang didirikan baik oleh seseorang atau sekelompok Akuntan Publik untuk menyediakan layanan yang sesuai dengan karakteristik profesi akuntan publik, menggunakan nama salah satu pendiri Akuntan Publik dan memperoleh izin usaha. Undang-Undang Nomor 5 tahun 2011 mendefinisikan KAP sebagai badan usaha yang didirikan berdasarkan ketentuan hukum dan memperoleh izin usaha berdasarkan ketentuan Undang-undang ini.

Standar Profesional Akuntan Publik SPAP SA Seksi 311 Paragraf 06: Auditor harus memperoleh pengetahuan tentang bisnis satuan usaha yang memungkinkannya untuk merencanakan dan melaksanakan auditnya berdasarkan standar auditing yang ditetapkan Ikatan Akuntan Indonesia. Tingkat pengetahuannya hams memungkinkan auditor untuk memahami peristiwa transaksi dan praktek yang menurut pertimbangannya kemungkinan mempunyai dampak terhadap laporan keuangan. Tingkat pengetahuan yang umumnya dimiliki manajemen tentang pengelolaan bisnis satuan usaha jauh lebih banyak apabila dibandingkan pengetahuan mengenai hal yang sama yang diperoleh auditor dari pelaksanaan auditnya. Pengetahuan tentang bisnis satuan usaha membantu auditor dalam:

a) Mengidentifikasi bidang yang memerlukan pertimbangan khusus.

b) Menilai kondisi yang di dalamnya data akuntansi dihasilkan, diolah, direview dan dikumpulkan dalam organisasi.

c) Menilai kewajaran estimasi, seperti penilaian atas asset, penyisihan kerugian piutang, persentase penyelesaian kontrak jangka panjang.

d) Menilai kewajaran representasi manajemen. 
e) Mempertimbangkan kesesuaian prinsip akuntansi yang diterapkan dan kecukupan pengungkapannya.

Paragraf 07: Auditor harus memperoleh pengetahuan mengenai hal-hal yang berkaitan dengan sifat bisnis satuan usaha, organisasinya dan karakteristik operasinya. Hal tersebut mencakup sebagai contoh tipe bisnis, tipe produk dan jasa, struktur modal, pihak yang mempunyai hubungan yang istimewa, lokasi dan metode produksi, distribusi dan kompensasinya. Auditor juga harus mempertimbangkan hal-hal yang mempengaruhi industri tempat operasi satuan usaha seperti kondisi ekonomi, peraturan pemerintah serta perubahan teknologi, yang berpengaruh terhadap auditnya. Hal lain harus dipertimbangkan auditor adalah praktek akuntansi yang umum berlaku dalam industri, kondisi persaingan, dan jika tersedia, tren keuangan dan rasio keuangan. Untuk lebih jelasnya tentang konsep pemahaman auditor terhadap program komputer, internet dan sistem e-commerce seperti pada pernyataanpernyataan diatas, dapat dilihat pada Standar Profesional Akuntan Publik berikut:

SPAP SA Seksi 335, Auditing Dalam Lingkungan Pengolahan Data Elektronik Tentang Keahlian dan kompetensi

Paragraf 03 :Bila melaksanakan audit dalam lingkungan pengolahan data elektronik, auditor harus memiliki pemahaman memadai mengenai perangkat keras, perangkat lunak dan sistem pengolahan komputer untuk merencanakan penugasan dan ia harus memahami bagaimana dampak pengolahan komputer untuk merencanakan penugasan dan ia harus memahami bagaimana dampak pengolahan sistem data elektronik terhadap prosedur yang digunakan oleh auditor dalam memperoleh pemahaman dan melakukan prosedur audit, termasuk penggunaan teknik audit berbantuan komputer (computer-assisted audit techniques).

Paragraf 04: Auditor harus pula memiliki pengetahuan pengolahan data elektronik memadai untuk menerapkan prosedur audit, tergantung atas pendekatan audit yang digunakan (audit around computer and through computer).

\section{Definisi Elektronik Commerce}

Ada beberapa definisi Electronic Commerce atau sering disebut disingkat menjadi e-commerce yaitu diantaranya yang diungkapkan oleh Fathul Wahid "Teknologi Informasi" (2002:97): ecommerce (Electronic Commerce) atau adalah bisnis yang transaksinya dilakukan dengan bantuan jaringan komputer secara on-line. Transaksi tersebut merupakan penjual dan pembeli barang atau jasa serta pembayarannya yang seluruhnya dilakukan melewati komunikasi digital 
elektronik. Teknologi yang digunakan antara lain adalah Internet dan electronic data interchange (EDI). Menurut Thomas $\mathrm{O}$ 'Daniel dalam bukunya "Electronic commerce, Management Economics Marketing and Technology”. (2000:3)

Dalam lingkungan TI yang kompleks, kualitas audit ditentukan oleh kompetensi, independensi dan sikap perawatan profesional karena yang dimiliki oleh auditor (Maria, 2010). Oleh karena itu, dalam proses audit menggunakan CAATs atau e-audit, auditor diperlukan untuk memahami struktur data, skema database dan proses bisnis (Braun dan Davis, 2003).

Pelaksanaan E-audit yang dilakukan oleh KAP di Indonesia menggunakan pendekatan audit tentang komputer karena tidak semua auditee sudah menggunakan sistem komputer terpadu (Budiasih, 2002). Sasongko (2002) menemukan bahwa tingkat pelaksanaan audit sistem informasi pada KAP di Indonesia masih sangat rendah. Namun, variabel usia Firm keseluruhan, kebutuhan dan dorongan dari KAP, khusus pengetahuan / pendidikan, instruksi / aturan / SPAP, dan e-audit pelaksanaan poin teknis memiliki dampak positif pada tingkat pelaksanaan audit sistem informasi. kinerja individu sangat dipengaruhi oleh budaya, keterampilan dan latar belakang pengetahuan yang mereka miliki (Esya, 2008). Sedangkan pendidikan akan menyebabkan perubahan perilaku sehingga orang akan mampu memecahkan masalah dengan pengetahuan mereka. Kombinasi pengalaman dan pendidikan akan meningkatkan kemampuan untuk melakukan tugas-tugas profesi akuntansi (Sasongko, 2002). Oleh karena itu, seharusnya bahwa implementasi e-audit di KAP akan mempengaruhi itu kinerja auditor mereka. Maka hipotesis yang akan diuji adalah:

H1: Penerapan E-audit memiliki pengaruh signifikan positif terhadap kinerja auditor di KAP Surabaya

\section{Kerangka Konseptual}

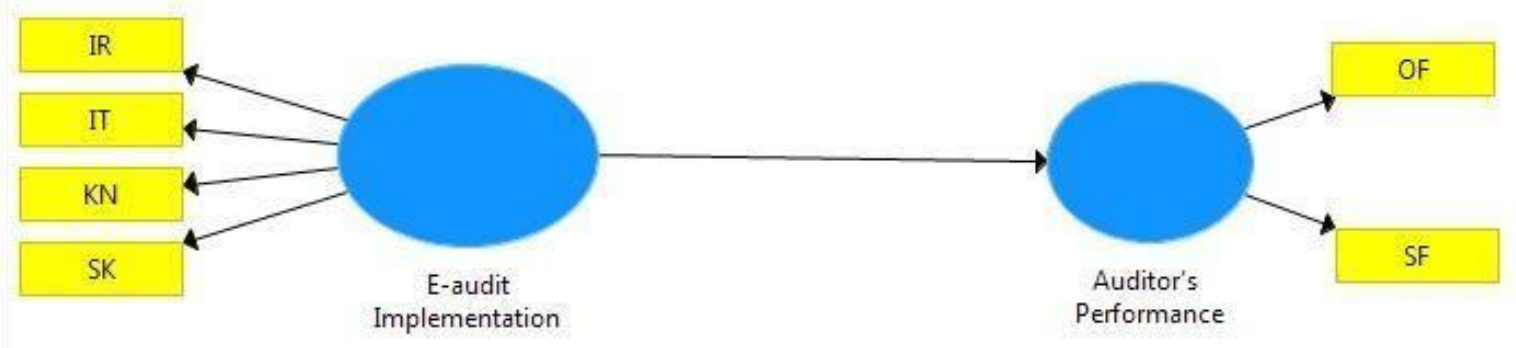

Gambar 1. Model Penelitian 


\section{METODE}

Penelitian ini menggunakan kuesioner sebagai instrumen penelitian. Kuesioner dibagikan kepada responden dalam bentuk kuesioner tertutup yang berisi daftar pernyataan dengan pilihan ganda, sehingga responden hanya bisa memilih jawaban yang telah disediakan. jawaban responden terhadap pernyataan dalam kuesioner didasarkan pada skala Likert.

\section{Tempat dan Waktu}

Data penelitian diperoleh dengan melakukan survei langsung dengan mengunjungi 10 KAP yang ada di Surabaya sebagai studi objek dengan tujuan untuk meningkatkan tingkat respon kuesioner dan peneliti bisa melihat proses pelaksanaan e-audit secara langsung. Waktu survei dan penyebaran kuesioner dilakukan pada tanggal 10-18 November 2017 di wilayah Surabaya.

\section{Populasi dan Sampel}

Populasi pada penelitian ini adalah Kantor Akuntan Publik dan rekan Auditor di wilayah Surabaya. Untuk sampel pada penelitian ini menggunakan purposive sampling karena kuesioner dibagikan kepada Auditor yang telah melakukan audit E-commerce dan menerapkan E-audit di KAP.

Para responden yang digunakan dalam penelitian ini adalah mitra, manajer, auditor senior, supervisor dan auditor junior yang bekerja di perusahaan-perusahaan di Surabaya dengan beberapa kriteria:

1. Telah bekerja di perusahaan minimal 3 (tiga) bulan

2. Memiliki kemampuan untuk menggunakan perangkat audit / perangkat lunak

3. Pernah menggunakan alat pemeriksaan / software dalam tugas audit.

Variabel yang dianalisis dalam penelitian ini adalah Penerapan e-audit sebagai variabel independen dengan menggunakan sub variabel seperti yang digunakan dalam studi oleh Sasongko (2002) mereka adalah usia KAP, dan KAP kebutuhan dan encouragement, khusus pengetahuan / pendidikan, instruksi / aturan / SPAP, dan e-audit pelaksanaan teknis poin. Eaudit variabel implementasi diukur dengan menggunakan 8 poin pernyataan. Sedangkan variabel dependen dari penelitian ini adalah kinerja auditor yang termasuk faktor-faktor 
objektif (hasil kerja dan disiplin kerja) dan subjektif faktor (prakarsa, kerjasama dan loyalitas). variabel kinerja auditor diukur dengan 19 poin pernyataan. Variabel-variabel ini berada di ordinal yang tingkat pengukuran dan metode skala yang digunakan di sini adalah Skala.

\section{Definisi Operasional dan Pengukuran Variabel}

Konstruk-konstruk yang digunakan dalam penelitian ini adalah Implementasi E-audit dan Auditor Performance. Pengukuran tiap-tiap konstruk menggunakan skala likert 1 sampai dengan 5 yang mempunyai arti (1) sangat tidak setuju, (2) tidak setuju, (3) netral, (4) setuju, dan (5) sangat setuju. Adapun jenis variabel, konstruk, definisi, indikator, serta kode indikator pada penelitian ini dijelaskan pada tabel 1 berikut :

Tabel 1. Konstruk, Dimensi, Pengukuran

\begin{tabular}{|c|c|c|c|c|c|}
\hline Jenis Variabel & Konstruk & Sumber & Dimensi & Indikator & $\begin{array}{c}\text { Kode } \\
\text { indikator }\end{array}$ \\
\hline \multirow[b]{2}{*}{$\begin{array}{l}\text { Variabel } \\
\text { Endogen } \\
\text { (Dependen) }\end{array}$} & \multirow[b]{2}{*}{$\begin{array}{l}\text { Kinerja } \\
\text { Auditor }\end{array}$} & \multirow[b]{2}{*}{$\begin{array}{l}\text { Esya, } \\
2008\end{array}$} & \multirow{2}{*}{$\begin{array}{l}\text { 1.Objective } \\
\text { Factor } \\
\text { 2.Subjective } \\
\text { Factor }\end{array}$} & $\begin{array}{l}\text { a. Hasil Kerja } \\
\text { b. Disiplin Kerja }\end{array}$ & $\mathrm{OF}$ \\
\hline & & & & $\begin{array}{l}\text { a. Pemikiran } \\
\text { Inisiatif } \\
\text { b. Bekerja Sama } \\
\text { c. Loyalitas }\end{array}$ & SF \\
\hline Jenis Variabel & Konstruk & Sumber & Dimensi & Indikator & $\begin{array}{c}\text { Kode } \\
\text { indikator }\end{array}$ \\
\hline \multirow[t]{2}{*}{$\begin{array}{l}\text { Variabel } \\
\text { Eksogen } \\
\text { (Independen) }\end{array}$} & \multirow[t]{2}{*}{$\begin{array}{l}\text { Penerapan } \\
\text { E-audit }\end{array}$} & \multirow[t]{2}{*}{$\begin{array}{l}\text { Hsien } \\
\text { Wu et, } \\
\text { al., } 2017\end{array}$} & $\begin{array}{l}\text { 1. Dorongan } \\
\text { Untuk } \\
\text { Penerapan E- } \\
\text { audit di KAP } \\
\text { 2. Pendidikan } \\
\text { dan } \\
\text { Pengetahuan } \\
\text { Khusus }\end{array}$ & $\begin{array}{l}\text { a) Kondisi dan } \\
\text { aturan kerja } \\
\text { b) Klien dan Dunia } \\
\text { bisnis } \\
\text { c) Kesadaran } \\
\text { Profesional dan } \\
\text { dorongan dari } \\
\text { organisasi } \\
\text { terkait }\end{array}$ & $\mathrm{KN}$ \\
\hline & & & $\begin{array}{l}\text { 3. Aturan dari } \\
\text { SPAP } \\
\text { 4. Pelaksanaan } \\
\text { E-audit }\end{array}$ & $\begin{array}{l}\text { a) Pengetahuan } \\
\text { komputer dasar } \\
\text { dan fungsi } \\
\text { lainya } \\
\text { b) Sistem operasi } \\
\text { dasar } \\
\text { c) Mengerti } \\
\text { tentang file } \\
\end{array}$ & SK \\
\hline
\end{tabular}


manajemen dan

sttruktur data

d) Penggunaan

dari software

audit

e) Kemampuan

mengulas dan

mendokumentas

ikan sistem

auditee

f) Pengetahuan

dasar sistem

EDP

g) Desain audit

dan pengawasan

di penerapan

EDP sistem

h) Pengetahuan

dari

pengembangan

sistem EDP

a) Penggunaan

buku panduan

audit dari KAP

internal atau

standard setter

b) Aplikasi audit

seperti ACL,

IDEA atau

pengembangan

aplikasi sendiri

dari KAP

a) Penggunaan

IT Software audit

b) Test data

c) Prosedur review analitis

d) Pengujian pengendalian umum dan aplikasi

e) Akses dokumen

f) Pengelompokan dokumen 
Teknik analisis kuantitatif digunakan untuk memproses dan membahas data yang dikumpulkan. Data yang diperoleh dari kuesioner dianalisis dengan menggunakan statistik parametrik untuk analisis data interval dan rasio. Karena data penelitian ini adalah dalam skala ordinal, data terlebih dahulu diubah menjadi data interval dengan menggunakan Metode Berturut-turut internal (MSI) sehingga statistik parametrik dapat digunakan. Alat analisis yang digunakan untuk menguji hipotesis adalah analisis regresi linier sederhana. Persamaan regresi adalah sebagai berikut:

$$
Y=a+b X+e
$$

Dimana:

$\mathrm{Y}=$ kinerja auditor

$\mathrm{a}=$ konstanta

$\mathrm{b}=$ koefisien regresi

$\mathrm{X}=\mathrm{e}$-audit implementasi

$\mathrm{e}=$ Standard error

Hipotesis akan diuji dengan langkah-langkah berikut (Sunyoto, 2011)

\section{Proses Pengolahan Data}

Analisa data dalam penelitian ini menggunakan SEM (Structural Equation Modelling) dengan aplikasi program PLS (Partial Least Square) versi 3.0.1PLS (Partial Least Square) dikembangkan pertama kali oleh wold sebagai metode, umum untuk mengestimasi path model yang menggunakan konstruk laten dengan multiple indikator. PLS (Partial Least Square) merupakan faktor indeterminacy suatu metode analisis yang bekerja sangat baik oleh karena tidak mengasumsikan data yang diolah harus dengan pengukuran skala tertentu, jumlah sampel yang kecil mampu menganalisa dengan baik. PLS (Partial Least Square) dapat juga digunakan untuk konfirmasi teori.

\section{HASIL}

\section{Profil Responden}

Penelitian ini dilakukan pada auditor yang bekerja di KAP di Surabaya dan auditor yang ikut termasuk mitra, manajer, supervisor, senior auditor dan auditor junior. Survei ini dilakukan pada bulan November 2017. Tetapi hanya 10 KAP yang mampu berpartisipasi dalam 
membantu penelitian ini sebagai responden 15 KAP lainnya menolak karena beralasan sibuk dalam tugas pemeriksaan. KAP yang berpartisipasi dalam penelitian ini termasuk KAP Drs. Arief H. P, KAP Adi Pramono \& Rekan, KAP Drs. Basri Hardjosumarto, M.Si, Ak \& Rekan, KAP Budiman, Wawan, Pamudji \& Rekan, KAP Habib Basuni, KAP Hadori Sugiarto Adi \& Rekan, KAP Soebandi \& Rekan, KAP Drs. Chandra Dwiyanto. Jumlah kuesioner yang diberikan kepada auditor yang sebanyak 100 kuesioner. Dari semua kuesioner yang dibagikan, hanya 60 (60\%) responden yang diisi dan dikembalikan kuesioner. Sementara yang lain tidak melengkapi dan mengembalikan kuesioner karena berbagai alasan.

\section{Pelaksanaan E-audit di Kantor Akuntan Publik di Surabaya}

Dari hasil survei dilakukan di 10 KAP di Surabaya pada bulan November 2017. Ditemukan pada berkas KAP bahwa auditee di Surabaya sudah menggunakan database. database yang digunakan seperti Microsoft Excel, Microsoft Access dan FoxPro. Dalam melakukan proses audit, KAP di Surabaya sudah menggunakan e-audit. KAP yang di survei tidak mengembangkan pemeriksaan perangkat lunak mereka sendiri tetapi mereka menggunakan Generalized Audit Software (GAS) seperti ACL, IDEA, Lotus Notes dan Spreadsheet. Meskipun GAS telah dikembangkan oleh beberapa auditor untuk memperoleh informasi audit dalam sebuah perusahaan yang menggunakan sistem informasi yang terkomputerisasi, tetapi perangkat lunak tidak kompatibel dengan struktur kompleks file dalam sistem database. Auditor biasanya mengalami kesulitan ketika mereka sedang menyiapkan data awal. 90\% KAP yang di survei masih menggunakan pendekatan audit sekitar komputer untuk membantu tugas-tugas auditee pemeriksaan di mana pendekatan ini auditor sering mengabaikan pemeriksaan tahap pengolahan data. Hal ini disebabkan tidak banyak auditor bisa mengambil keuntungan dari akses ke peran IT mulai dari input ke proses output.

Auditor tidak memiliki keahlian yang cukup untuk mengumpulkan dan mengevaluasi bukti elektronik dan sebagian besar auditor masih menggunakan pendekatan audit untuk bukti fisik dari bukti elektronik. Sebagai tambahan, Faktor ukuran bisnis auditee juga dipengaruhi proses pengambilan keputusan auditor perangkat lunak apa yang akan digunakan dalam melakukan audit. 


\section{Validitas dan Reliabilitas Test:}

Corrected Item Total Koefisien Korelasi digunakan untuk menguji validitas indikator, sementara Cronbach Alpha digunakan dalam pengujian reliabilitas indikator. Berdasarkan hasil pengujian untuk setiap pernyataan variabel pada e-audit implementasi dan Kinerja Auditor.

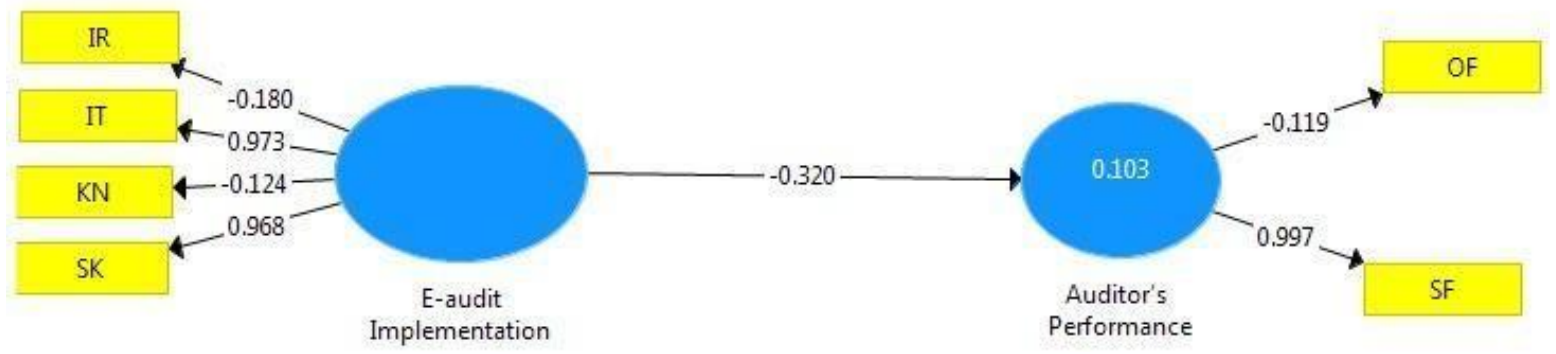

\section{Gambar 2. Cross Loading}

Berdasarkan Outer Loading diatas, maka indikator Instruction Rule dan KAP needs encouragement pada Variabel E-audit dan indikator Objek Faktor pada variabel Auditor Performance dikeluarkan dari model karena memiliki loading kurang dari 0.50 dan tidak signifikan. Discriminant validity indikator reflektif dapat dilihat pada cross-loading antara indikator dengan konstruknya dengan menggunakan PLS Algorithm report pilih discriminant validity lalu cross loading berikut ini output smartPLS.

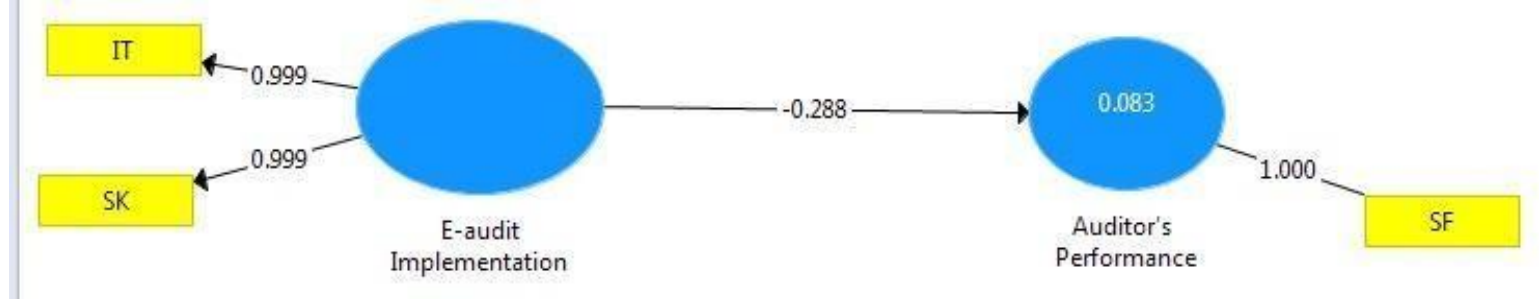

Gambar 3. Cross Loading

Sekarang hasilnya telah memenuhi convergent validity karena semua Factor loading berada diatas 0.50 .

Tabel 2. Construct Reliability and Validity

\begin{tabular}{lccc}
\hline & $\begin{array}{c}\text { Cronbach's } \\
\text { Alpha }\end{array}$ & \multicolumn{1}{l}{$\begin{array}{l}\text { Composite } \\
\text { Reliability }\end{array}$} & \multicolumn{2}{c}{$\begin{array}{c}\text { Average Variance } \\
\text { Extracted (AVE) }\end{array}$} \\
\hline Auditors & 1,000 & 1,000 & 1,000 \\
Performance & 0,998 & 0,999 & 0,998 \\
E-audit & & & \\
\hline
\end{tabular}

Untuk menilai validitas dari konstruk dengan melihat nilai AVE, dipersyaratkan model yang baik kalau AVE masing-masing konstruk nilainya $>0,50$. Hasil Output diatas 
menunjukkan bahwa konstruk E-audit maupun Auditor Performance memiliki nilai yang lebih besar dari 0.50 .

Untuk menguji reliabilitas konstruk yang diukur dengan dua kriteria yaitu dengan composite reliability dan Cronbach alpha dari blok indikator yang mengukur konstruk. Konstruk dinyatakan reliabel jika nilai keduanya diatas 0.70 . Hasil output keduanya diatas menunjukkan nilai konstruk E-audit maupun Auditor Performance memiliki nilai diatas 0.70 jadi dapat disimpulkan bahwa konstruk memiliki reliabilitas yang baik.

Tabel 3. Discriminant Validity

\begin{tabular}{lrr}
\hline & $\begin{array}{c}\text { Auditors } \\
\text { Performance }\end{array}$ & E-audit \\
\hline Auditors & 1,000 & \\
Performance & $-0,288$ & 0,999 \\
E-audit & \\
\hline
\end{tabular}

Untuk menilai kriteria Discriminant Validity, dari tabel diatas diketahui bahwa nilai indikator dengan variabel seperti nilai indikator IT yang mempunyai nilai 0,999 terhadap variabel E-audit lebih tinggi dari pada korelasi antara konstruk audit performance yang hanya sebesar -0,293, begitu pula indikator lainnya telah memenuhi kriteria discriminant validity.

Tabel 4. Latent Variable

\begin{tabular}{lrr}
\hline & $\begin{array}{c}\text { Auditors } \\
\text { Performance }\end{array}$ & E-audit \\
\hline Auditors & 1,000 & $-0,288$ \\
Performance & $-0,288$ & 0,999 \\
E-audit & \\
\hline
\end{tabular}

Untuk kriteria Latent Variabel hampir sama dengan Discriminant Validity. Dari hasil output diatas menunjukkan bahwa korelasi sesama konstruk lebih besar dari pada cross construct.

\section{Pengujian Model Struktural (Inner Model)}

Tabel 5. R Square

\begin{tabular}{lrr}
\hline & R Square & R Square Adjusted \\
\hline Auditors Performance & 0,83 & 0,67 \\
\hline
\end{tabular}

Pengujian terhadap model structural dilakukan dengan melihat nilai R-square yang merupakan uji goodness-fit model. Model pengaruh E-audit terhadap Auditor Performance memberikan nilai R-Square sebesar 0,83 yang dapat diinterpretasikan bahwa variabilitas 
konstruk Auditor Performance yang dapat dijelaskan oleh variabilitas konstruk E-audit sebesar $83 \%$ sedangkan $17 \%$ dijelaskan oleh variabel lain diluar yang diteliti.

\section{Pengujian Hipotesis}

Pengujian hipotesis digunakan untuk menentukan apakah hipotesis diterima atau ditolak dengan mengeksplorasi dampak dari penerapan e-audit terhadap kinerja auditor di Kantor Akuntan Publik. Semua pengujian dan analisis data dalam penelitian ini digunakan SmartPLS 3.0 (Program statistik untuk Ilmu khusus) untuk windows. Hasil pengujian dengan analisis regresi dapat dilihat pada Tabel di bawah ini.

Tabel 6. Path Coefficient

\begin{tabular}{lcrrrr}
\hline & $\begin{array}{c}\text { Original } \\
\text { sample (0) }\end{array}$ & $\begin{array}{c}\text { Sample } \\
\text { Mean (M) }\end{array}$ & $\begin{array}{c}\text { Standard Deviation } \\
\text { (STDEV) }\end{array}$ & $\begin{array}{c}\text { T Statistics } \\
\text { (0/STDEV) }\end{array}$ & $\begin{array}{c}\text { P } \\
\text { Values }\end{array}$ \\
\hline $\begin{array}{l}\text { E-Audit }-> \\
\text { Auditors }\end{array}$ & 0,288 & $-0,282$ & 0,103 & 2,814 & 0,005 \\
Performance & & & & & \\
\hline
\end{tabular}

Hasil pengujian hipotesis pada Tabel menunjukkan bahwa pelaksanaan e-audit memiliki dampak yang signifikan terhadap kinerja auditor. variabel kinerja auditor atas pelaksanaan E-audit mengakibatkan arah arah regresi positif sebesar 0,288. jadi semakin tinggi penerapan E-audit maka semakin baik Performa auditor. Dengan nilai t statistic sebesar 2,814 $>$ 1,96 signifikan (t tabel signifikansi 5\%=1,96).

Hasil penelitian ini konsisten dengan penelitian yang dilakukan oleh Hartoyo (2011), Evi Mariya, Yayuk Ariyani (2014) dan Sasongko (2002) yang menyatakan bahwa implementasi e-audit di KAP bisa meningkatkan kinerja auditor. program pendidikan, pelatihan dan bantuan teknis yang terkait dengan penggunaan teknologi informasi dalam eaudit perlu dilakukan secara terus-menerus (Sasongko, 2002).

Kinerja auditor meningkat karena ke pelaksanaan pengumpulan data dan proses pemeriksaan dengan menggunakan e-audit ditemukan lebih cepat dari cara konvensional. Kemajuan teknologi bisa membuat auditor untuk memastikan pengendalian internal dari auditee, untuk mengakses dokumen dan catatan serta menghasilkan informasi yang lebih efisien yang tidak dapat dilakukan dengan menggunakan pendekatan audit manual. Dari manfaat penerapan e-audit, dari KAP harus memiliki pertimbangan hati-hati, terutama mengenai tingkat auditor penerimaan teknologi baru yang digunakan dalam e-audit. Karena kunci untuk implementasi e-audit yang sukses didasarkan pada penerimaan auditor yang 
meliputi harapan kinerja, harapan, sebagai mudah menggunakan e-audit, pengaruh sosial sebagai kesadaran pengaruh orang lain untuk menggunakan e-audit dan harapan pengguna pada infrastruktur organisasi dan poin teknis dapat mendukung sistem berjalan.

Jika implementasi e-audit memiliki dampak pada peningkatan kinerja auditor, maka peningkatan kinerja secara otomatis akan meningkatkan kualitas audit dan laporan yang dihasilkannya. Koefisien determinasi menunjukkan bahwa $83 \%$ dari variasi yang terjadi pada kinerja auditor dapat dijelaskan oleh pelaksanaan e-audit dan sisanya $27 \%$ dipengaruhi oleh variabel lain selain pelaksanaan e-audit yang tidak dibahas dalam penelitian ini.

\section{KESIMPULAN}

Penggunaan pengolahan data elektronik (EDP) oleh perusahaan telah membawa perubahan tidak hanya dalam bidang akuntansi tetapi juga di bidang audit. Kantor Akuntan Publik (KAP) di Indonesia, khususnya di Surabaya meningkatkan kualitas audit terus menerus dengan menerapkan e-audit dalam proses audit mereka sejak auditee KAP sudah menggunakan sistem EDP dalam memproses transaksi bisnis mereka. Studi ini menemukan bahwa perusahaan-perusahaan di Surabaya telah dilaksanakan e-audit di penugasan audit dengan menggunakan Generalized Audit Software (GAS), 90,90\% masih menggunakan pendekatan audit KAP sekitar komputer karena auditor memiliki keahlian yang terbatas dalam penggunaan IT dan sisanya 9,10\% sudah menggunakan pendekatan audit melalui komputer. KAP sebagai organisasi legal untuk mendukung proses penugasan audit.

Dari hasil tes itu menemukan bukti empiris bahwa implementasi e-audit di KAP memiliki pengaruh positif dan signifikan terhadap kinerja auditor dari mana semakin tinggi pelaksanaan e-audit, semakin tinggi itu auditor kinerja. Auditor kinerja dipengaruhi oleh faktor e-audit ( $83 \%)$ dan sisanya dipengaruhi oleh faktor lain yang tidak diamati dalam penelitian ini misalnya orientasi etika dan komitmen untuk profesi. Karena implementasi e-audit memiliki kontribusi besar terhadap peningkatan kinerja auditor, dari kepala perusahaan harus mempertimbangkan tingkat auditor penerimaan teknologi audit yang baru termasuk harapan kinerja, ekspektasi usaha, pengaruh sosial, dan harapan dari pengguna dalam organisasi dan infrastruktur teknis untuk mendukung sistem berjalan. 


\section{DAFTAR PUSTAKA}

Esya, Febri Purnama. (2008). Pengaruh Kompetensi Auditor dan Pemahaman Sistem Informasi Akuntansi terhadap Kinerja Auditor Bea dan Cukai di Jakarta. Medan: Universitas Sumatera Utara.

Hartoyo, Agung Dwi. (2011). Upaya Peningkatan Kinerja Pemeriksaan BPK RI menggunakan Computer Assisted Audit Techniques. Konferensi Teknologi Informasi dan Komunikasi Untuk Indonesia. Bandung.

IAPI. (2013). Standar Profesional Akuntan Publik (SPAP). Jakarta: Salemba Empat.

Mulyadi. (2010). Auditing. 6 Volume V Issue 3, Sep. 20147 www.scholarshub.net Th ed. Jakarta: Salemba Empat. ISBN 978-979-691-019-9

Sasongko, Nanang. (2002). Audit Sistem Informasi: Analisis Faktor-Faktor yang Mempengaruhi Tingkat Penerapannya pada Kantor Akuntan Publik (KAP) di Indonesia. Proceedings Komputer dan Sistem Intelejen (KOMMIT). Universitas Gunadarma, C19-26.

Evi Maria,Yayuk ariyani.(2014).E-Commerce Impact: The Impact Of E-Audit Implementation on The Auditor's Performance.

Khemakhe, J. (2001). Integral Auditing. International Journal of Governmental Auditing. 28(2).

Carlos Santos (2013). The impact of e-commerce on the internal Control and on auditing practices

Mahd Ali Al jabali.(2011). The Impact of E-commerce on the Audit Profession in Jordan

Jeffrey, C. and N. Weatherholt. (1996). Ethical Development, Profesional Commitment, and Rule Observance Attitudes. Behavioral Research in Accounting, 8, 8-36.

Pathak, Jagdish, (2006), "Empirical Assessment of Effective E-Commerce Audit Judgment", Paper No. 977851, online available: (www.ssrn.com).

Pathak, Jagdish, (2006), "Audit Resource Planning Success in B2B E-Commerce Engagement: An Empirical Assessment of Theorized Constructs, Manifest Variables Measurement and Second Order Factor Model", Paper No. 899040, online available: (www.ssrn.com). 